\title{
Assay of the Infectivity of Epstein-Barr Virus by Transformation of Human Leucocytes in vitro
}

\author{
(Accepted 19 July 1972)
}

One of the important biological activities of EB virus (Epstein, Achong \& Barr, 1964) is the transformation of human leucocytes in vitro (Henle et al. I967; Pope, Horne \& Scott, 1968). Transformation in this context is defined as morphological change in a proportion of the cells, associated with continued cell proliferation leading to establishment of a lymphoid cell line. The transformation factor was identified as EB virus by showing that it had some of the general properties of herpes viruses and was neutralized specifically by human sera containing antibody to EB virus (Pope, Horne \& Scott, I969).

The all-or-none nature of the transformation response to EB virus makes it a suitable basis for assay of virus infectivity. Some experiments have been reported of titration of EB virus by transformation assay in I $\mathrm{ml}$ leucocyte cultures (Pope et al. 1969, 197I) and of the distribution of infectivity in a sucrose density gradient (Walters \& Pope, I97I). These preliminary investigations showed that the method was feasible, but the large number of leucocytes required prevented the preparation of sufficient cultures to allow detailed studies. The present report described a micromethod which overcomes many of the earlier handicaps by providing a large number of replicate leucocyte cultures which are suitable for transformation by EB virus.

Adult venous or cord blood was collected in sodium citrate (Dacie \& Lewis, 1968), layered on top of a mixture of Hypaque (Winthrop Laboratories, Sydney, Australia) and methylcellulose (Dow Chemical Co., Michigan, U.S.A.) according to the method of Main \& Jones (I968), and the leucocyte containing plasma collected. The leucocytes were sedimented at about $300 \mathrm{~g}$ for $5 \mathrm{~min}$ and resuspended at $10^{6} \mathrm{cells} / \mathrm{ml}$ in culture medium R.P.M.I. 1640 (Grand Island Biological Co., Grand Island, N.Y., U.S.A.) containing $16 \%$ inactivated foetal calf serum, penicillin (IOo units/ml), streptomycin (I00 $\mu \mathrm{g} / \mathrm{ml}$ ) and I4 mM- $N-2-$ hydroxyethylpiperazine- $N$-2-ethanesulphonic acid (HEPES)(Calbiochem, Los Angeles, Cal., U.S.A.), with the $\mathrm{pH}$ adjusted to 6.8 with $\mathrm{HCl}$ before use. The leucocyte suspension was distributed into 'Micro Test II' tissue culture plates (3040, Falcon Plastics, Cal., U.S.A.) using $0.15 \mathrm{ml} /$ well. The cultures were then held in the incubator $\left(5 \% \mathrm{CO}_{2}\right.$ in air, humidified, $\left.36^{\circ} \mathrm{C}\right)$ until inoculation.

The QIMR-WIL lymphoid cell line (Pope, I968) used as the source of EB virus was cultivated in Eagle's minimum essential medium (GIBCO, F-I5) containing Io \% foetal calf serum and penicillin, streptomycin and HEPES as above. Filtered virus preparations were prepared from harvested cells essentially as previously described (Pope et al. 1968) except that the cell extracts were made up in R.P.M.I. I640 growth medium and filtered only through Millipore membranes (Millipore Corporation, Bedford, Mass., U.S.A.) of $300 \mathrm{~nm}$ average pore diameter. Culture fluids harvested for extracellular virus were frozen and thawed, filtered and stored frozen. Control inocula were prepared by similar methods from cells of the Raji line (Pulvertaft, 1965) which was free of EB virus particles (Epstein et al. 1966). All virus preparations were stored at $-60^{\circ} \mathrm{C}$.

Tenfold dilutions of EB virus pools were prepared in 1640 growth medium, commonly to $\mathrm{IO}^{-6}$. Each dilution was inoculated into six replicate leucocyte cultures, each culture 
receiving $0.02 \mathrm{ml}$ by micropipette. After inoculation, the plastic lid was sealed onto the plate by adhesive tape, and the plates returned to the incubator. During incubation condensation sometimes formed on the surface of the plate and lid, and was carefully absorbed with a sterile paper tissue before the culture fluid was changed.

Approximately $30 \%$ of the fluid was changed twice weekly. This otherwise laborious task was made somewhat simpler and more accurate by use of a stainless-steel suction manifold which could remove the required amount of fluid from a row of eight wells at once. The manifold was sterilized by flaming and allowed to cool between rows. New medium was added by Pasteur pipettes and the plates sealed again.

The cultures were examined at regular intervals on a Leitz inverted microscope (E. Leitz, Wetzlar, Germany) at regular intervals for I month. The first sign of transformation was the formation of small aggregates of irregular cells. Continued proliferation of these cells, with concurrent formation of large aggregates, indicated unequivocal transformation. Usually proliferation of the transformed cells continued for the whole observation period but in some cultures, inoculated with the most concentrated virus filtrates, the transformed cells grew actively for about I week then steadily deteriorated.

When infective preparations of EB virus were titrated the average period before transformation increased gradually with virus dilution, from a minimum of about I week with undiluted virus to about 3 weeks with dilutions of $10^{-3}$ or $10^{-4}$. Under these conditions transformation rarely occurred later than 3 weeks after inoculation. Transformation occurred uniformly in all cultures receiving dilutions below the endpoint region. The use of six replicate cultures allowed the titre of infectivity to be calculated by the method of Reed \& Muench (1938) and the titre was expressed as the TCD $50 / \mathrm{ml}$.

During the course of the first experiments there was nothing in the pattern of transformation in the plates to suggest that any cross-contamination by virus had occurred. The cells tended to remain at the bottom of the wells and accidental transfer of transformed cells from one well to another seemed very unlikely. None the less, in order to check for any possible spread of virus or cells in the plate, a row of wells containing leucocytes was left uninoculated between the rows receiving undiluted and $\mathrm{IO}^{-1}$ virus. No cross-contamination has been detected since this precaution was taken but it was considered prudent to include such a control on a routine basis.

In order to assess its general applicability, the new assay method was used to follow the levels of infective EB virus in the QIMR-WIL cell line. Two QIMR-WIL cultures were diluted $\mathrm{I} / 3$ in growth medium and a sample harvested daily for I week. Cell viability was recorded daily and filtrates of cell extracts and of culture fluid prepared and stored as already described. On the day of assay, replicate cultures were prepared from about $40 \mathrm{ml}$ of adult venous blood and all stored samples were diluted and inoculated. No transformation occurred in control cultures inoculated with Raji filtrates, but that which occurred in cultures inoculated with EB virus dilutions in I month was recorded. The results of two experiments are shown in Figs. I and 2. The results were similar and showed that the level of cell-associated EB virus capable of transforming cells was highest up to 3 to 4 days after subculture and thereafter decreased quite rapidly. In contrast, the level of transforming virus in the extracellular fluid remained at a fairly constant level throughout the week. The titre observed in cell extracts was up to $1 \mathrm{O}^{3}$ higher than that recorded in fluid and the peak titre was associated with the peak viability of the culture.

These results are applicable to particular cultures of a particular line (QIMR-WIL) of human lymphoid cells as experience has shown that the level of virus in QIMR-WIL cells can vary tremendously, apparently depending upon conditions of culture. However, the work 


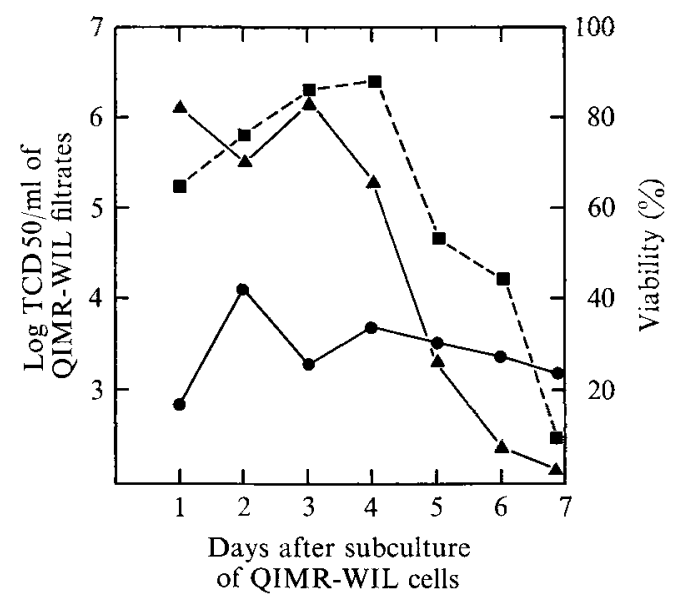

Fig. I

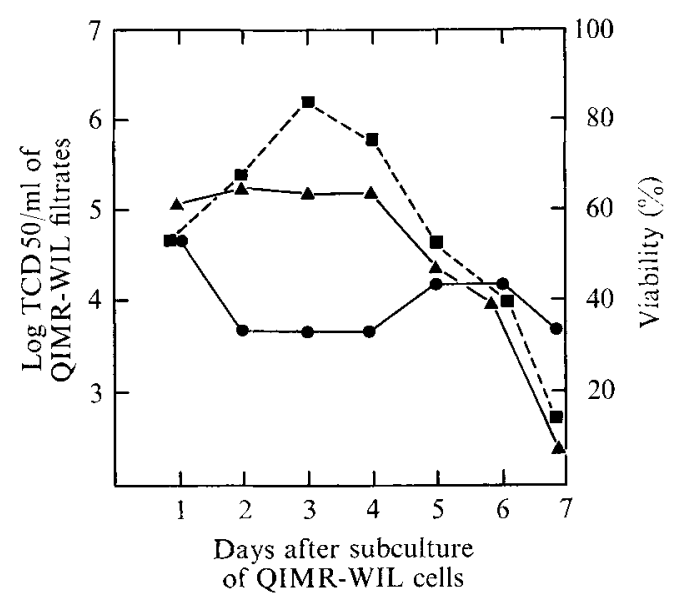

Fig. 2

Figs. I, 2. Levels of EB virus in the QIMR-WIL cell line after subculture, as determined by transformation assays. The levels of cell-associated virus $(\boldsymbol{\Delta}-\mathbf{\Delta})$ and extracellular virus are shown, together with the cell viability

so far clearly shows that this micromethod is quite suitable for accurate assay of the infectivity of EB virus by means of transformation. It is expected that, apart from allowing some vital basic information to be obtained, the present assay will find application in several important aspects of research into EB virus.

Queensland Institute of Medical Research,

D. J. Moss

Herston Road, Brisbane, Queensland, Australia

J. H. POPE 


\section{REFERENCES}

DACIE, J. V. \& LEWIS, S. M. (I968). Practical Haematology, $4^{\text {th }}$ ed., p. 5. London: J. and A. Churchill Ltd. EPSTEIN, M. A., ACHONG, B. G. \& BARR, Y. M. (I964). Virus particles in cultured lymphoblasts from Burkitt's lymphoma. Lancet i, 702-703.

EPSTEIN, M. A., ACHONG, B. G., BARR, Y. M., ZAJAC, B. A., HENLE, G. \& HENLE, W. (I966). Morphological and virological investigations on cultured Burkitt tumor lymphoblasts (strain RAJI). Journal of the National Cancer Institute 37, 547-559.

HENLE, W., DIEHL, V., KOHN, G., ZUR HAUSEN, H. \& HENLE, G. (1967). Herpes-type virus and chromosome marker in normal leukocytes after growth with irradiated Burkitt cells. Science, New York 157, I064-I065. MAIN, R. K. \& JONES, M. J. (1968). Mixed leucocyte interaction involving mouse strains of strong and weak allogeneic specificities. Nature, London 218, I25I-1252.

POPE, J. H. (I968). Establishment of cell lines from Australian leukaemic patients: presence of a herpes-like virus. The Australian Journal of Experimental Biology and Medical Science 46, 643-645.

POPE, J. H., HORNE, M. K. \& SCOTT, W. (I968). Transformation of foetal human leukocytes in vitro by filtrates of a leukaemic cell line containing herpes-like virus. International Journal of Cancer 3,857-866.

POPE, J. H., HORNE, M. K. \& SCOTT, W. (I969). Identification of the filtrable leukocyte-transforming factor of QIMR-WIL cells as herpes-like virus. International Journal of Cancer 4, 255-260.

POPE, J. H., SCOTT, W., REEDMAN, B. M. \& WALTERS, M. K. (I97I). EB virus as a biologically active agent. Proceedings of the First International Symposium of the Princess Takamatsu Cancer Research Fund, pp. 177-I 88. Edited by W. Nakahara, K. Nishioka, T. Hirayama \& Y. Ito.

PULVERTAFT, R. J. V. (1965). A study of malignant tumours in Nigeria by short-term tissue culture. Journal of Clinical Pathology 18, 261-27I.

REED, L. J. \& MUENCH, H. (1938). A simple method of estimating fifty per cent endpoints. American Journal of Hygiene 27, 493-497.

WALTERS, M. K. \& POPE, J. H. (197I). Studies of the EB virus-related antigens of human leukocyte cell lines. International Journal of Cancer 8, 32-40.

(Received 30 May 1972) 